\title{
在宅血液透析を目的とした自己穿刺補助具の開発
}

\author{
古 薗 勉 ${ }^{1}$ 森 義 博 $^{2}$ 太田 雅 顕 $^{2}$ 長谷川 晋也 ${ }^{2}$ \\ 坂巻 正倫 ${ }^{2}$ 松 本 良 平 $^{2}$ 横山和 $コ^{2}$ 坂井 瑠 実 $^{3}$ \\ 国立循環器病センター研究所先進医工学センター生体工学部 ${ }^{1}$ \\ 日機装株式会社静岡製作所 ${ }^{2} \quad$ 芦屋坂井瑠実クリニック ${ }^{3}$
}

キーワード：在宅血液透析，自己穿刺，補助具，バスキュラーアクセス

〈要旨〉

在宅血液透析における患者による自己穿刺の容易性を高めるため，自己穿刺補助具を開発した．補助具のプロト タイプは三次元立体造形技術により, アクリロニトリル・ブタジエン・スチレン共重合体 (ABS) 樹脂を用いて製造 された. 当該補助具は，台座部，延設部，アーム部，突起部，および血管を圧迫固定するための弾性的な付勢手段 としてのトーションバネから主に構成された. 穿刺する際, アーム部をトーションバネの付勢力に抗して摇動させ て腕を挿通し，突起部にて血管を押圧する．さらに，その押圧状態から患者の腕を穿刺方向にわずかにずらすこと により，血管を伸展固定できるように設計された.

\section{Development of a self-cannulation support device for home hemodialysis}

Tsutomu Furuzono', Yoshihiro Mori', Masaaki Ohta², Shinya Hasegawa², Masamichi Sakamaki ${ }^{2}$, Ryohei Matsumoto ${ }^{2}$, Kazumi Yokoyama ${ }^{2}$ and Rumi Sakai ${ }^{3}$

Department of Bioengineering, Advanced Medical Engineering Center, National Cardiovascular Center Research Institute $^{1}$; Shizuoka Plant, Nikkiso Co., Ltd. ${ }^{2}$; Ashiya Sakai Rumi Clinic ${ }^{3}$

Key words : home hemodialysis, self-cannulation, support device, vascular access

〈Abstract〉

A self-cannulation support device for home hemodialysis was developed in order to increase the ease of selftreatment by patients. The prototype model made of acrylonitrile-butadiene-styrene (ABS) resin was manufactured using three-dimensional modeling technology. The device was mainly composed of a basement, expansion/contraction, arm, projection, and torsion spring parts. Especially, the arm of the device was energized by the spring to press and fix a venous vessel of the patient's forearm. When cannulation is conducted, the patient's forearm is inserted into the aperture between the basement and the arm of the device. The patient's vessel was pressed by the projecting part and subsequently fixed by a slight movement of the patient's forearm in the direction of cannulation.

はじめに

わが国では，1998 年に在宅血液透析（home hemodialysis, HHD）が保険収載されてから, HHD 患者数 はわずかずつではあるが徐々に増え続け, 2008 年末に 194 人に達した ${ }^{1)}$. HHD では通院や決められた透析ス ケジュールの遵守等の時間的な制限が緩和されるた
め, 短時間連日血液透析 (short daily hemodialysis, SDHD）や連日夜間血液透析（nocturnal daily hemodialysis）などの頻回透析が選択されやすい環境にあ る. その結果, 心機能の改善 ${ }^{2}, \mathrm{QOL}^{3)}$ や生存率の向

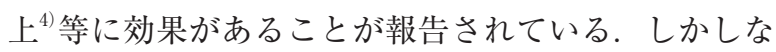
がら, 現在の HHD 患者数は全慢性透析患者数 ( 282,622 人) のわずか $0.07 \%$ にかすぎず1), 慢性腎 不全の治療法として高い効果が認められつつも, 爆発

古䓟 勉 国立循環器病センター研究所先進医工学センター生体工学部 † 565-8565 大阪府吹田市藤白台 5-7-1

Tsutomu Furuzono Tel : 06-6833-5012 Fax : 06-6872-7485 E-mail : furuzono@ri.ncvc.go.jp

〔受付日：2009 年 8 月 3 日, 受理日：2009 年 10 月 22 日〕 


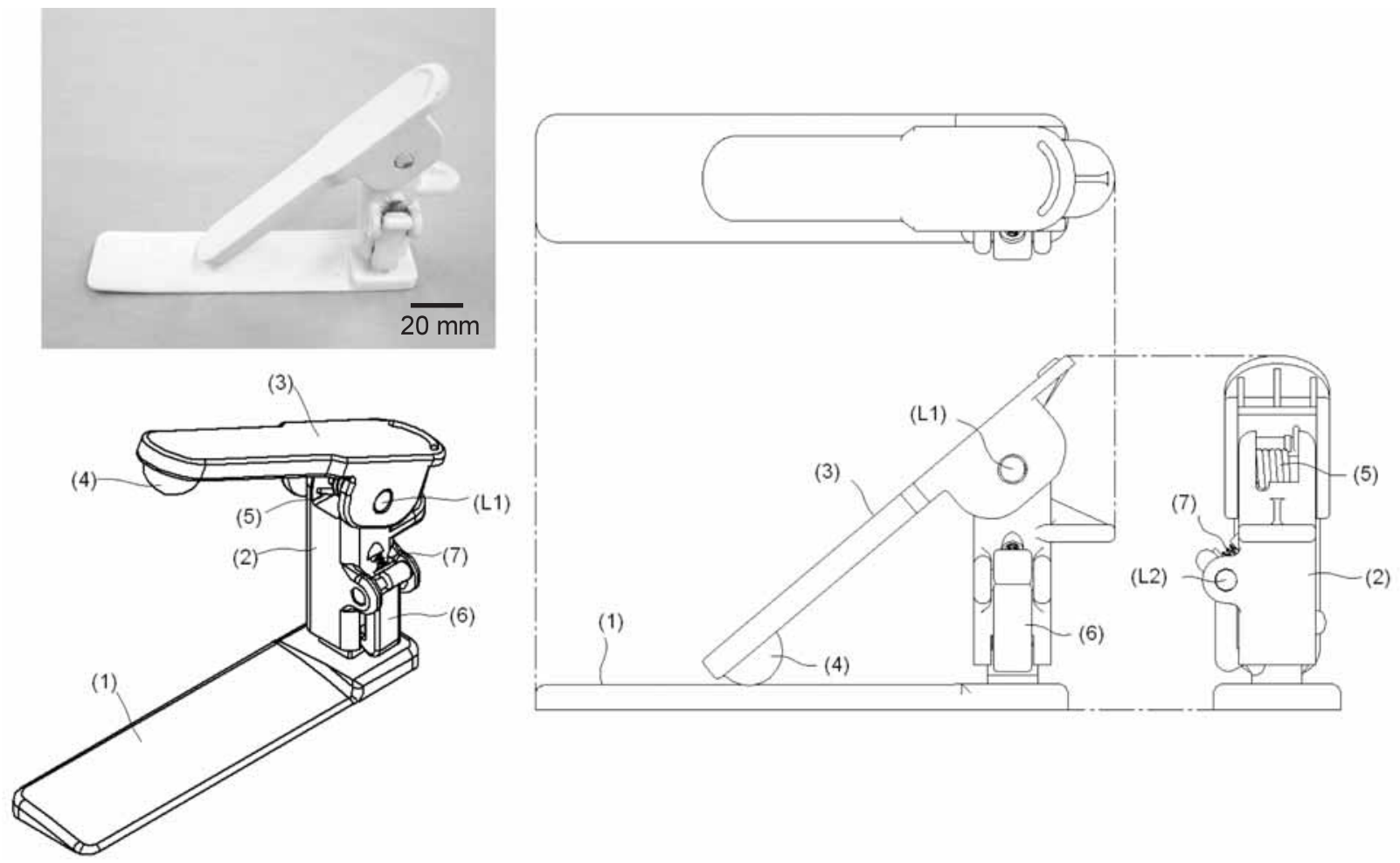

図 1 自己穿刺補助具の構造と外観

構成部品の名称：(1) 台座部, (2) 延設部, (3) アーム部, (4) 突起部,

(5)トーションバネ, (6)ロック爪, (7)スプリング, (L1)-(L2) 摇動軸

的な広がりは影を潜めている。その治療法の低い選択 性の理由として，自己穿刺に対する敬遠と介助者の必 要性等があげられている ${ }^{5,6)}$. 特に介助者は治療開始 時から終了時まで必ず存在しなければならず，これが 毎日のこととなると介助者の心的ストレスは計り知れ ない。 もちろん介助者の存在は必須であるが, 介助者 を不測の事態が生じたときの緊急対応者として位置づ けるならば，患者本人が一人で透析治療の全工程を行 うことができれば, 介助者のストレスの軽減を図るこ とができると思われる。また，透析開始時に患者が一 人で容易に自己穿刺が可能となれば，HHD を治療法 の選択肢として捉える患者が増加すると期待される.

以上の観点から，本研究では，自己穿刺の容易性の 向上を目的として自己穿刺をアシストするデバイスを 開発したので報告する。

\section{I . 製造方法}

自己穿刺補助具のプロトタイプは，三次元立体造形 技術を用いて構成部品を直接立体的に加工した後, 組 み立て製造された。主要な構成部品の材質は，成形性 および機械的強度に優れるアクリロニトリル・ブタジ エン・スチレン共重合体（ABS）樹脂を用いた。これ
らの構成部品は成形加工後, 表面研磨し白色に塗装さ れた。ささらに別途に加工したステンレス製スプリング およびゴム製の突起部材と，前述した ABS 樹脂製部 品とを組み立てることにより自己穿刺補助具のプロト タイプを完成させた。

\section{II . 結果および考察}

穿刺の際, 施術者は患者の上腕を適当な力で駆血し, 血管を十分な程度まで怒張させる。 さらに穿刺目標と する血管を触診にて確認し，さらに伸展固定すること により，血管の移動を防ぎつつ穿刺することが一般的 に行われている，在宅血液透析の場合，施術者の介助 に頼らず患者本人が穿刺する場合，血管の伸展固定が 十分に図れず，血管の移動によって穿刺に少なからず 困難をきたす場合がある。従って，患者本人が穿刺を 行うかもしくは介助者が穿刺を行うかを問わず，穿刺 する血管の移動抑制のための伸展固定は通常, 介助者 によって行われる場合が多い。本報告では, 穿刺時に おける施術者の基本動作をデバイスによって代替し， 患者本人による穿刺を容易に実施可能とする補助具を 考案した。

図 1 に自己穿刺補助具の構造および外観を示す。当 

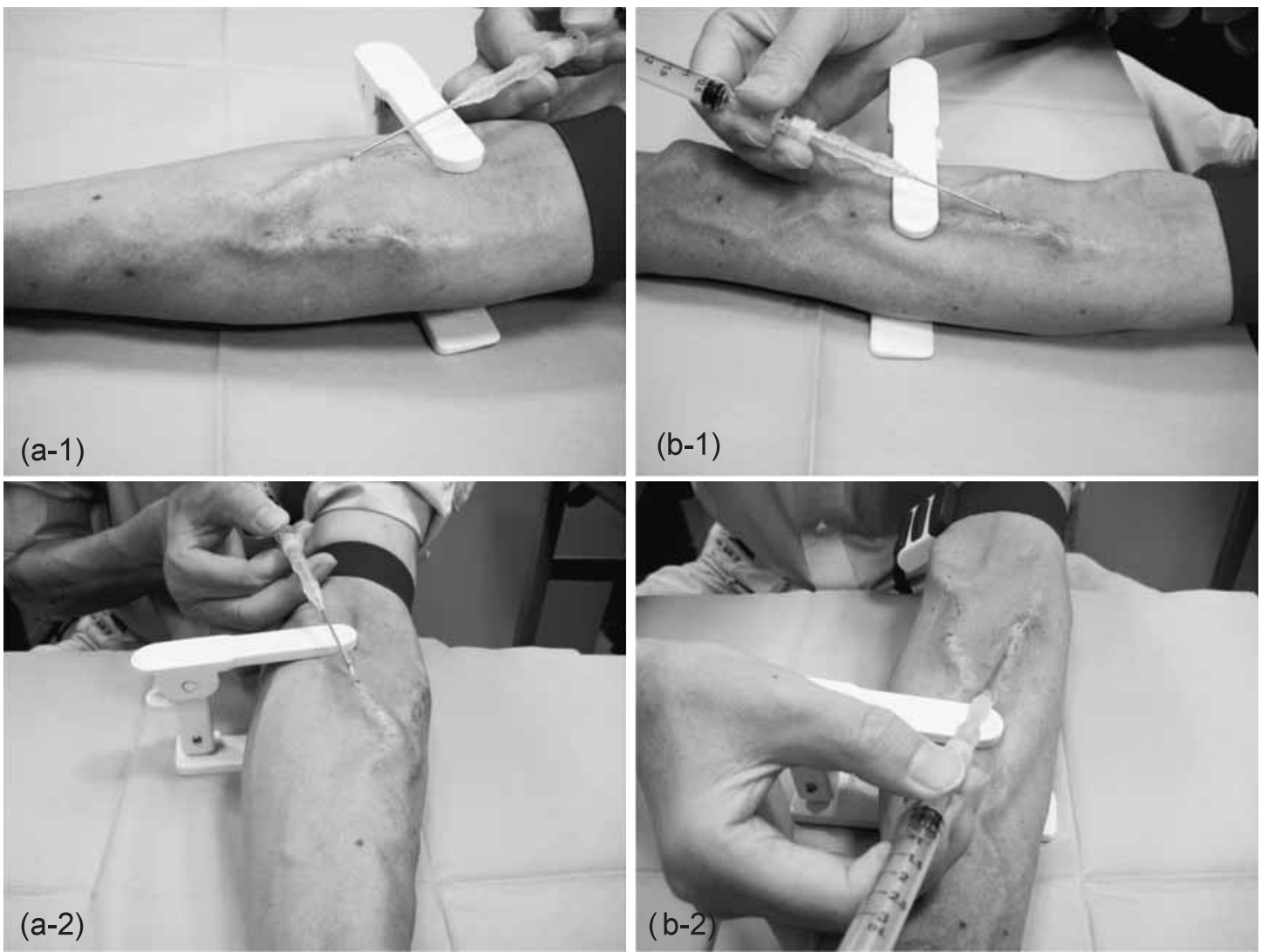

図 2 自己穿刺補助具使用時のイメージ写真

(a-1,2) 中枢側から末梢側に向けた穿刺像. 腕を末梢側に押し込むことで血管 を伸展させる。

（b-1,2）末梢側から中枢側に向けた穿刺像．腕を中枢側に引くことで血管を 伸展させる。

該補助具は，台座部 (1)，延設部 (2)，アーム部 (3)，突 起部 (4)，㧍よび血管を圧迫固定するための弾性的な 付勢手段としてトーションバネ (5) から主に構成され ている. 台座部（1）はオーバーヘッドテーブルなどの 平坦な任意の場所に載置可能な板状部材からなる．患 者の腕の㨂通方向に対して若干の勾配をもたせるこ と，拉よび裏面に滑り止め加工を施すことによって補 助具を固定する際に安定性を高めている，延設部 (2) は台座部端から上方に延設されている，延設部内側に 複数の段が設けられた柱があり，延設部外側の筒に装 着されたロック爪 (6)によって延設部の長さを制御し, 患者の腕の太さに合わせて当該補助具を装着できるよ うに設計されている。アーム部（3）は延設部との接続 部にある摇動軸（L1）を中心に上下に摇動し，血管を 圧迫固定する仕組みになっている。 アーム部が平板状 構造をなしている理由は, 穿刺する際に穿刺針やハン ドリングの邪魔にならないように考慮されているため である。アーム部先端にある突起部 (4) は台座部と対 向する所定部位にゴム部材を取り付けたもので，血管 を圧迫する部位である。トーションバネ (5) はアーム
部の先端が台座部に当接する方向に常時付勢し，血管 を圧迫固定するための力を発生させるものである.

使用前の自己穿刺補助具は，アーム部の先端と台座 部が接触した形態をなす (図 1 中央). 図 2 に当該補 助具を用いた自己穿刺のイメージ写真を示す. 穿刺す る際，上腕を適当な強さで駆血し十分に血管を怒張さ せる、アーム部をトーションバネの付勢力に抗して摇 動させ，穿刺を施す側の前腕を㨂通し，突起部にて押 圧することによって血管を固定する，さらにその押圧 状態から患者の腕を穿刺方向にわずかにずらすことに より，血管を伸展固定できる，具体的には図 2 に示す とおり，自己穿刺補助具を中心として前腕を固定し， 腕を末梢側に押し込みながら血管を伸展固定し末梢側 に位置する血管に穿刺する（a-1，2）。もしくは，腕を 中枢側に引きながら血管を伸展固定し中枢側に位置す る血管に穿刺する（b-1，2）。また橈側もしくは尺側 からも穿刺が可能である。 アーム部抒よび先端の突起 部は穿刺時に障害にならないような厚みに設計されて いるため, アーム部自体が穿刺時の障害になることは なく適当な挿入角度で穿刺が可能である。これらの様 
子は，施術者が患者の腕に穿刺する直前の状態を模倣 している.

ところで，これまでいくつかの穿刺補助具が考案さ れている. 例えば, $2 つ の$ 棒状部材を対向配置させて 血管を挟むように血管走行方向に沿って当接する構造 体 ${ }^{7)}$ ，血管の両側に沿って皮膚上に対向配置される血 管固定部からなる構造体 ${ }^{8)}$ および血管の穿刺位置を 挟んで対向して前腕に接触させる構造体 ${ }^{9}$ が報告され ている.いずれの穿刺補助具も皮膚から静脈血管を挟 んで固定する構造体であり，医療行為を行う施術者が 取扱うことを前提として考案されている，従って，患 者本人がこれらの補助具を用いて自己穿刺することは 構造上不可能である.

当該自己穿刺補助具はボタンホール穿刺にも適用す ることが可能である. ボタンホール穿刺法とは, 同じ 穿刺部位に毎回穿刺し続けることで，皮膚から血管内 へ容易に針の挿入ルートを形成させる方法である ${ }^{10)}$. この方法を用いると穿刺の痛みの回避抒よびシャント 血管寿命の延長が可能とされている. ボタンホールが 形成されてからは, 通常, 先端を鈍状加工したダルニー ドルやペインレスニードル等が使用されている。この 場合，針先が皮虐孔を介して血管表面に達した後，し ばしば針先が血管の穿刺孔を探り当てることができず に穿刺が不完全となる場合がある，患者が自己穿刺す る場合，当該補助具を用いることにより，皮膚孔と直 下の血管孔のズレを抑制し，比較的容易に穿刺孔を探 り当てアクセスを図ることができると期待される.

また，当該補助具は自己穿刺だけではなく，抜針時 において止血補助具としても有用である。具体的に は，一連の血液透析治療が終了し抜針の際，皮虚穿刺 部を脱脂綿やガーゼ等で覆った状態で, 当該補助具の 付勢力を利用して突起部 (4)により血管を圧迫して止 血を図ることができる.

\section{まとめ}

在宅血液透析の穿刺において介助者の手助けを必要 とせず，患者本人による穿刺に有用な補助具を開発し
た. 当該補助具は台座部, 延設部, アーム部, 突起部, および血管を圧迫固定するための弾性的な付勢手段と してトーションバネから主に構成されていた，当該補 助具を用いて自己穿刺を患者一人で害施できる環境を 付与することにより, 患者の自立性の向上抢よび介助 者の心的ストレスの軽減を図れ, 在宅血液透析拡大の 一助となると期待される. 当該補助具は厚生労働省医 療機器審査室より医療機器分類クラス I （不具合が生 じた場合でも人体へのリスクが極めて低いと考元られ るもの）に相当との通知を受けており，現在上市およ び臨床応用に向けて鋭意努力を重ねている.

\section{文献}

1) 日本透析医学会統計調查委員会：わが国の慢性透析療 法の現状 (2008 年 12 月 31 日現在). 日本透析医学会, 東京, 2009

2) Buoncristiani U, Fagugli RM, Pinciaroli MR, Kulurianu H, Ceravolo G, Bova C : Reversal of left-ventricular hypertrophy in uremic patients by treatment with daily hemodialysis (DHD). Contrib Nephrol 119: 152156, 1996

3) Koshikawa S, Akizawa T, Saito A, Kurokawa K : Clinical effect of short daily in-center hemodialysis. Clin Pract 95 : c23-c30, 2003

4) Mastrangelo F, Alfonso L, Napoli M, DeBlasi V, Russo $\mathrm{F}$, Patruno P : Dialysis with increased frequency of sessions (Lecce dialysis). Nephrol Dial Transplant 13 (Suppl 6) : 139-147, 1998

5）小関 修：「血液透析患者実態調查報告」にみる在宅血 液透析普及の条件．臨林透析 $20 ： 1338-1340,2004$

6）和田朋子, 菅原育子, 高橋弥生, 松田真弓, 佐々木信 弥, 金田英之, 政金生人 : 在宅血液透析推進一の試み. 臨林透析 $24: 1682-1683,2008$

7) 野尻佳克: 針穿刺補助具. 実用新案登録第 3112638 (登 録日）2005.7.13

8）長谷川正規：血管穿刺用針の刺し入れ補助具. 特開 2002-272844（公開日）2002.9.24

9) 有賀恒紀, 三池信也: 穿刺補助具. 特開 2003-79724 (公 開日）2003.3.18

10）新里高弘, 當間茂樹 : 在宅血液透析に適したアクセ久 血管の穿刺法．臨林透析 $23: 1395-1400,2007$ 